\title{
Pilot Testing of Mercury Oxidation Catalysts for Upstream of Wet FGD Systems
}

\author{
Quarterly Technical Progress Report
}

July 1, 2003 - September 30, 2003

Prepared by:

Gary M. Blythe

October 2003

Cooperative Agreement No: DE-FC26-01NT41185

URS Corporation

9400 Amberglen Boulevard

Austin, Texas 78729

\section{Prepared for:}

Bruce Lani

National Energy Technology Laboratory

U.S. Department of Energy

626 Cochrans Mill Road

Pittsburgh, Pennsylvania 15236 


\section{DISCLAIMER}

This report was prepared as an account of work sponsored by an agency of the United States Government. Neither the United States Government nor any agency thereof, nor any of their employees, makes any warranty, express or implied, or assumes any legal liability or responsibility for the accuracy, completeness, or usefulness of any information, apparatus, product, or process disclosed, or represents that its use would not infringe privately owned rights. Reference herein to any specific commercial product, process, or service by trade name, trademark, manufacturer, or otherwise does not necessarily constitute or imply its endorsement, recommendation, or favoring by the United States Government or any agency thereof. The views and opinions of authors expressed herein do not necessarily state or reflect those of the United States Government or any agency thereof. 


\section{ABSTRACT}

This document summarizes progress on Cooperative Agreement DE-FC26-01NT41185, "Pilot Testing of Mercury Oxidation Catalysts for Upstream of Wet FGD Systems," during the timeperiod July 1, 2003 through Septebmer 30, 2003. The objective of this project is to demonstrate at pilot scale the use of solid honeycomb catalysts to promote the oxidation of elemental mercury in the flue gas from coal combustion. The project is being funded by the U.S. DOE National Energy Technology Laboratory under Cooperative Agreement DE-FC26-01NT41185. EPRI, Great River Energy (GRE), and City Public Service (CPS) of San Antonio are project cofunders. URS Group is the prime contractor.

The mercury control process under development uses catalyst materials applied to honeycomb substrates to promote the oxidation of elemental mercury in the flue gas from coal-fired power plants that have wet lime or limestone flue gas desulfurization (FGD) systems. Oxidized mercury is removed in the wet FGD absorbers and co-precipitates with the byproducts from the FGD system. The current project is testing previously identified, effective catalyst materials at a larger, pilot scale and in a commercial form, to provide engineering data for future full-scale designs. The pilot-scale tests will continue for approximately 14 months at each of two sites to provide longer-term catalyst life data.

This is the eighth full reporting period for the subject Cooperative Agreement. During this period, project efforts included continued operation of the first pilot unit at the GRE Coal Creek site with all four catalysts in service and sonic horns installed for on-line catalyst cleaning. During the quarter, a catalyst activity measurement trip and mercury SCEM relative accuracy tests were completed, and catalyst pressure drop was closely monitored with the sonic horns in operation. CPS completed the installation of the second mercury oxidation catalyst pilot unit at their Spruce Plant during the quarter, and the four catalysts to be tested in that unit were ordered. The pilot unit was started up with two of the four catalysts in service late in August, and initial catalyst activity results were measured in late September. The other two catalysts will not become available for testing until sometime in October. This technical progress report details these efforts at both sites. 


\section{TABLE OF CONTENTS}

Page

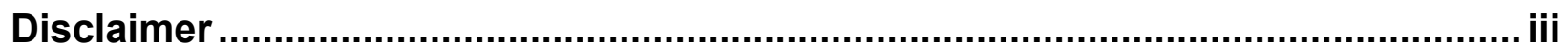

Abstract........................................................................................................................ iv

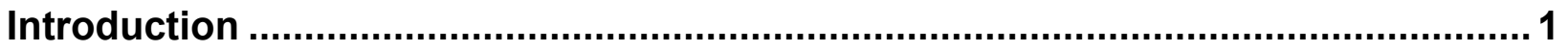

Executive Summary ............................................................................................ 2

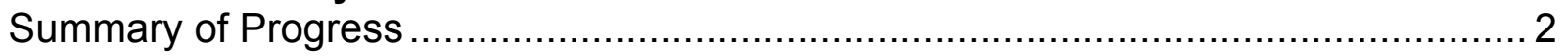

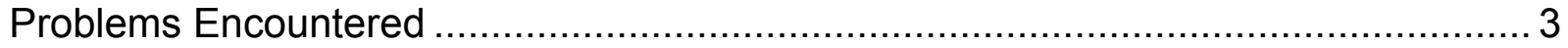

Plans for Next Reporting Period ................................................................... 3

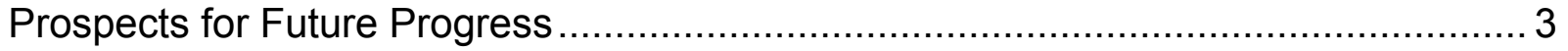

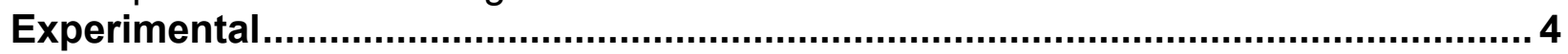

Results and Discussion ................................................................................... 5

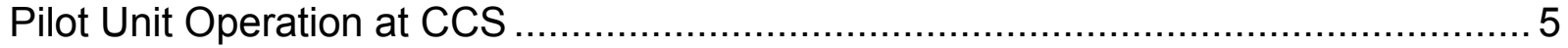

Laboratory Evaluation of Candidate Catalysts ............................................. 12

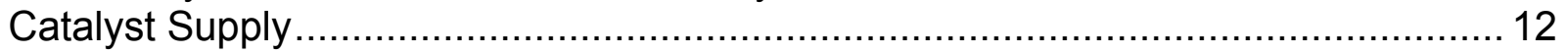

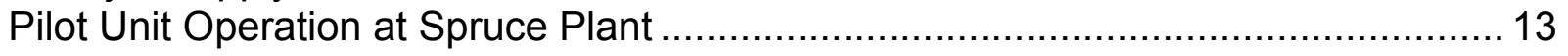

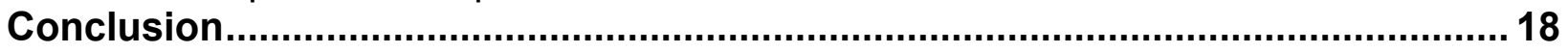

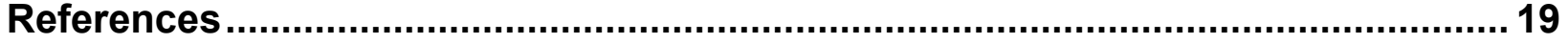




\section{INTRODUCTION}

This document is the quarterly Technical Progress Report for the project "Pilot Testing of Mercury Oxidation Catalysts for Upstream of Wet FGD Systems," for the time-period July 1, 2003 through September 30,2003. The objective of this project is to demonstrate at pilot scale the use of solid honeycomb catalysts to promote the oxidation of elemental mercury in the flue gas from coal combustion. The project is being funded by the U.S. DOE National Energy Technology Laboratory under Cooperative Agreement DE-FC26-01NT41185. EPRI, Great River Energy (GRE) and City Public Service (CPS) of San Antonio are project co-funders. URS Group is the prime contractor.

The mercury control process under development uses catalyst materials applied to honeycomb substrates to promote the oxidation of elemental mercury in the flue gas from coal-fired power plants that have wet lime or limestone flue gas desulfurization (FGD) systems. The oxidizing species are already present in the flue gas, and may include chlorine, hydrochloric acid $(\mathrm{HCl})$ and/or other species. Oxidized mercury is removed in the wet FGD absorbers and co-precipitates with the byproducts from the FGD system. The objective of this project is to test previously identified effective catalyst materials at a larger scale and in a commercial form to provide engineering data for future full-scale designs. The pilot-scale tests will continue for approximately 14 months at each of two sites to provide longer-term catalyst life data. After successful completion of the project, it is expected that sufficient full-scale test data will be available to design and implement demonstration-scale or commercial-scale installations of the catalytic mercury oxidation technology.

The two utility team members are providing co-funding, technical input, and host sites for testing. GRE is providing the first test site at their Coal Creek Station (CCS), which fires a North Dakota lignite, and CPS is providing the second site at their J.K. Spruce Plant, which fires a Powder River Basin (PRB) subbituminous coal. These two host sites each have existing wet FGD systems downstream of high-efficiency particulate control devices, an ESP at CCS and a reverse-gas fabric filter at Spruce.

The remainder of this report is divided into five sections: an Executive Summary followed by a section that describes Experimental procedures, then sections for Results and Discussion, Conclusions, and References. 


\section{EXECUTIVE SUMMARY}

\section{Summary of Progress}

The current reporting period, July 1, 2003 through September 30, 2003, is the eighth full technical progress reporting period for the project. Efforts over the current period included continued operation of the first mercury oxidation catalyst pilot unit at the CCS site with all four catalysts installed and sonic horns in operation for on-line catalyst cleaning, and initial operation of the second pilot unit at CPS' Spruce plant.

The pilot unit at CCS is installed at the outlet of an induced draft fan and downstream of the cold-side electrostatic precipitator on Unit 1. An SCR catalyst and a palladium-based catalyst (Pd \#1) have been in operation since October 3, 2002. A subbituminous ash-based catalyst, SBA \#5, was installed in the pilot unit the first week in December 2003. The fourth, Carbon \#6 (C \#6) catalyst was installed and placed in service on June 5, 2003. During the current quarter, catalyst activity measurements were made at the CCS site, and mercury SCEM relative accuracy and other gas characterization tests were conducted using the Ontario Hydro method.

After four months of operation with sonic horns in service for on-line catalyst cleaning, they appear to be effective in limiting fly ash buildup in the horizontal gas flow catalysts, at least for three of the four catalysts. After four months, the pressure drop across the Pd \#1 and C \#6 catalysts remain at about 0.3 in. $\mathrm{H}_{2} \mathrm{O}$ (both at a $2000 \mathrm{acfm}$ flue gas flow rate), and the pressure drop across the SCR catalyst (at $1500 \mathrm{acfm}$ ) is about $0.2 \mathrm{in} . \mathrm{H}_{2} \mathrm{O}$. The pressure drop is slowly increasing with time across the fourth, SBA \#5 catalyst, and was up to about $0.8 \mathrm{in} . \mathrm{H}_{2} \mathrm{O}$ by the end of the quarter.

A catalyst activity measurement trip was conducted the week of July 21 , and showed high activity ( $>80 \% \mathrm{Hg}^{0}$ oxidation) for the $\mathrm{Pd} \# 1$ and new $\mathrm{C} \# 6$ catalysts but significantly lower activity ( $<50 \%$ oxidation) for the SCR and SBA \#5 catalysts, as measured with a mercury SCEM. However, the Ontario Hydro relative accuracy tests did not show good agreement with the SCEM results, and showed higher activities for all four catalysts, particularly the SCR catalyst.

Installation of the second pilot unit, which was built with EPRI funding, was completed at CPS' Spruce Plant during the quarter. The four catalysts to be tested at Spruce were ordered, and two were received and put in operation in the pilot unit in late August. Initial catalyst activity results were measured at Spruce in late September. These measurements showed that the fabric filter outlet flue gas mercury content is highly oxidized ( $>75 \%)$, which is surprising for a PRB flue gas. The two catalysts ( $\mathrm{Pd} \# 1$ and gold $[\mathrm{Au}]$ ) showed 80 to $85 \%$ oxidation of the remaining elemental mercury. The Spruce pilot unit was brought off line on September 26 as the host plant began a fall outage. The pilot unit will be placed back in service on or about October 27, when the host plant comes back on line. It is expected that all four catalysts will be available and will be installed when the pilot unit is placed back in service.

A subcontract was issued and completed during the current reporting period to Süd-Chemie Prototech for the procurement of the Pd \#1 and Au catalysts for Spruce Plant, and a subcontract 
was issued to a catalyst manufacturer that wishes to remain anonymous for preparation of the $\mathrm{C}$ \#6 catalyst. The effort is expected to be completed in October.

\section{Problems Encountered}

There were no significant new problems encountered during the reporting period, other than the technical issues described in Section 4 of this report and mentioned above.

\section{Plans for Next Reporting Period}

The next reporting period covers the time-period October 1 through December 31, 2003. The pilot unit at CCS will remain in operation with all four catalysts in service and sonic horns operating in each compartment to prevent fly ash buildup. Routine sampling trips will be conducted to evaluate catalyst activity at CCS. The original project schedule called for pilot unit operation to end after 14 months in service ( December 2003). However, the schedule has been extended because the $\mathrm{C} \# 6$ catalyst has only been operation since June, and more operating time is needed to be able to predict its life. It is expected the pilot unit at CCS will operate at least until April 2004.

Operation of a second oxidation catalyst pilot unit, at CPS' Spruce Plant, should restart soon after the host unit comes back on line October 27. It is expected that all four catalysts will be installed by that time. During the coming quarter, an intensive flue gas sampling trip (Ontario Hydro measurements across each catalyst chamber) is scheduled to occur.

\section{Prospects for Future Progress}

During the subsequent reporting period (January 1 through March 31, 2004), both pilot units will remain in operation and will be evaluated for elemental mercury oxidation activity through routine ( $\sim$ monthly to bimonthly) evaluation trips. In following quarters, a final intensive flue gas sampling trip will occur at the end of the long-term catalyst evaluation period at CCS ( April 2004), after which the pilot unit will be shut down. At the second site, CPS' Spruce Plant, pilot

unit operation should continue until the end of calendar year 2004. Intensive gas characterization efforts for the Spruce Plant site should occur approximately in May 2004 and November or December 2004. 


\section{EXPERIMENTAL}

The work described in this technical progress report was conducted using two different experimental apparatuses. One is an elemental mercury catalyst oxidation pilot unit (8000 acfm of flue gas treated) located at GRE's CCS Station in North Dakota. A second, nearly identical pilot unit is located at CPS' Spruce Plant. Each pilot unit has four separate compartments that allow four different catalysts to treat flue gas from downstream of the host plant's particulate control device and upstream of its FGD system. Details of the pilot unit design, construction, catalyst preparation and pilot unit operation have been discussed in previous quarterly technical progress reports ${ }^{1,2,3,4}$. The activity of these catalysts is being determined by measuring the change in elemental mercury concentration across each catalyst, while ensuring that the total mercury concentrations do not change significantly across the catalyst. These measurements are primarily being conducted using a mercury semi-continuous emissions monitor (SCEM) developed with funding from EPRI. The analyzer has been described in a previous report ${ }^{5}$. Periodically, the analyzer results are being verified by conducting manual flue gas sampling efforts in parallel across each catalyst chamber by the Ontario Hydro method.

The second experimental apparatus is a bench-scale test unit that is used to evaluate the activity of candidate catalyst cores under simulated flue gas conditions. The testing is being conducted at simulation gas flow rates of approximately 1 to $2 \mathrm{nl} / \mathrm{min}$. The simulation gases contain a mixture of compressed gases intended to approximate flue gas compositions at the pilot unit host sites. The simulation gases include nitrogen, oxygen, carbon dioxide, water vapor, sulfur dioxide, nitrogen oxides, hydrochloric acid, elemental mercury, and a small amount of mercuric chloride. As for the pilot units, an EPRI mercury SCEM is used to measure catalyst activity for oxidizing elemental mercury in the simulation gases. The bench-scale catalyst oxidation test apparatus has also been previously described in quarterly technical progress reports ${ }^{3,4}$. 


\section{RESULTS AND DISCUSSION}

This section provides details of technical results for the current reporting period, July 1, 2003 through September 30, 2003. The technical results presented include a discussion of the data from pilot unit testing at CCS and from the second pilot unit at CPS' Spruce Plant.

\section{Pilot Unit Operation at CCS}

As described in the previous quarterly reports, the first pilot unit was started up at CCS with the SCR and Pd \#1 catalysts the first week of October 2002. The other two catalysts (SBA \#5 and C \#6) were not yet available, so testing began with only two of the four catalysts installed. Initial catalyst activity measurements were made using the EPRI mercury SCEM, which has been described in earlier progress reports. October 2002 results showed high activity for the Pd\#1 catalyst, over $90 \%$ of elemental mercury across the catalyst, as was expected based on previous laboratory and field tests with this material. The SCR catalyst results showed significantly lower oxidation percentages at the same flue gas flow rates, in the range of 60 to $70 \%$ oxidation of elemental mercury across the catalyst. Throughout this report, the elemental mercury oxidation percentages across catalysts are reported based on the drop in elemental mercury concentration across the catalyst, and do not just reflect the total flue gas mercury oxidation percentage at the catalyst outlet.

By December 2002, measurement results showed a marked decrease in activity for both catalysts. The percentage oxidation of elemental mercury across Pd \#1 dropped from greater than $90 \%$ in October to $50-70 \%$ in December, and across the SCR catalyst dropped from $60-70 \%$ in October to $20-30 \%$ in December. Follow-up testing in January determined that the catalyst surfaces were becoming plugged due to a buildup of fly ash, in spite of the catalyst being installed downstream of a high-efficiency ESP. This was confirmed by observed pressure drop increases across the catalyst chambers, and by physically inspecting the catalysts to observe and clean out the fly ash buildup.

The third catalyst, SBA \#5, was installed in December, 2002. The January trip provided the first opportunity to measure the activity of the SBA \#5 catalyst after it had time to achieve adsorption equilibrium. However, it too was adversely affected by fly ash buildup.

It was decided that a method of mechanical cleaning should be implemented on the pilot unit. Both air soot blowers and sonic horns were considered. After reviewing full-scale SCR experience with on-line catalyst cleaning and talking to a number of soot blower and sonic horn vendors, it was decided that a sonic horn would be the easiest field retrofit at CCS and would offer a good probability of success. A small, 17-inch horn produced by Analytec Corporation of Pagosa Springs, Colorado appeared to be the best solution based on price, availability, and probability of success. During the last week of March 2003, an Analytec sonic horn was installed on the Pd \#1 catalyst box to provide an occasional pulse of acoustic energy to the catalysts to dislodge accumulated particulate matter. The horn was installed on the top wall of the catalyst housing inlet transition, approximately 1.5 feet upstream of the first catalyst module. The horn was programmed to sound for 10 seconds every half hour. 
At the time the sonic horn was installed, the catalyst housing was opened and the Pd \#1 catalyst modules were cleaned. The plan was that, if effective, a horn would be subsequently be installed on each of the other catalyst chambers. After the pilot unit was placed back in service on March 27 , it was seen that the horn was effective at controlling the pressure drop across the Pd \#1 catalyst. However, the ultimate effectiveness of the horn could not be confirmed until it was verified that the $\mathrm{Pd} \# 1$ catalyst also retained high activity. A catalyst activity measurement trip was conducted the week of April 23 to determine whether the horn allowed the Pd \#1 catalyst to remain at high activity for elemental mercury oxidation. Activity results showed that the Pd \#1 catalyst, after being kept clean with the sonic horn, was achieving about $90 \%$ oxidation of elemental mercury while the "dirty" SCR and SBA \#5 catalysts were relatively inactive (10-12\% elemental mercury oxidation).

The Pd \#1 results were confounded by apparent mercury adsorption seen across the catalyst (i.e., some of the drop in elemental mercury concentration across the Pd \#1 could be due to adsorption rather than oxidation). In spite of this confounding effect, the $\mathrm{Pd} \# 1$ results were taken to be quite encouraging. Elemental mercury concentrations of nearly $10 \mu \mathrm{g} / \mathrm{Nm}^{3}$ at the inlet were lowered to an average of $1.0 \mu \mathrm{g} / \mathrm{Nm}^{3}$ at the outlet of that catalyst, with some measurements as low as $0.6 \mu \mathrm{g} / \mathrm{Nm}^{3}$. Based on the relatively high activity and low pressure drop values for Pd \#1, similar Analytec sonic horns were procured and installed on the other three boxes by CCS plant personnel the first week of June.

The pilot unit was restarted on June 5 with all four catalysts installed and the sonic horns in service on each compartment (10 seconds each every 30 minutes). A catalyst performance measurement trip was conducted after approximately one week in operation. The results from this trip (using the EPRI Hg SCEM for measurements) showed that the Pd \#1 remained highly active ( $90 \%$ elemental mercury oxidation at $2000 \mathrm{acfm}$ ) and that the new catalyst (C \#6) appeared to be very active (97\% oxidation). Both of these catalysts were still adsorbing some $\mathrm{Hg}$ at the time of these measurements $(\sim 15 \%$ adsorption by the $\mathrm{Pd}, 25 \%$ by the $\mathrm{C} \# 6)$, so these results could be biased slightly. The SCR catalyst and SBA \#5 fly ash catalyst results were less encouraging. These catalysts were measured to achieve about $30 \%$ elemental mercury oxidation at their normal flue gas flow rates.

With the horns in service, the pressure drop across three of the four catalysts has stayed very low. The pressure drop values since June 5 are plotted in Figure 1. By the end of September, the pressure drop for three of the four catalyst chambers measured within about 0.1 in. $\mathrm{H}_{2} \mathrm{O}$ of their initial pressure drops when they were restarted after cleaning on June 5. At the end of September, the Pd \#1 and C \#6 pressure drops were about 0.3 in. $\mathrm{H}_{2} \mathrm{O}$, and the SCR catalyst (larger pitch and 1500 acfm flow rate) was about 0.2 in. $\mathrm{H}_{2} \mathrm{O}$. The SBA \#5 pressure drop continued to slowly increase with time, though, to about 0.8 in. $\mathrm{H}_{2} \mathrm{O}$ by the end of September, more than double the initial pressure drop on June 5. However, this catalyst was apparently adversely affected by a pilot unit trip in late May, which trapped wet, cool flue gas in contact with the fly ash coated catalysts. Also, this catalyst type is of lesser interest for future commercial applications. Thus, the pressure drop increase across this particular catalyst chamber is not of great concern. 


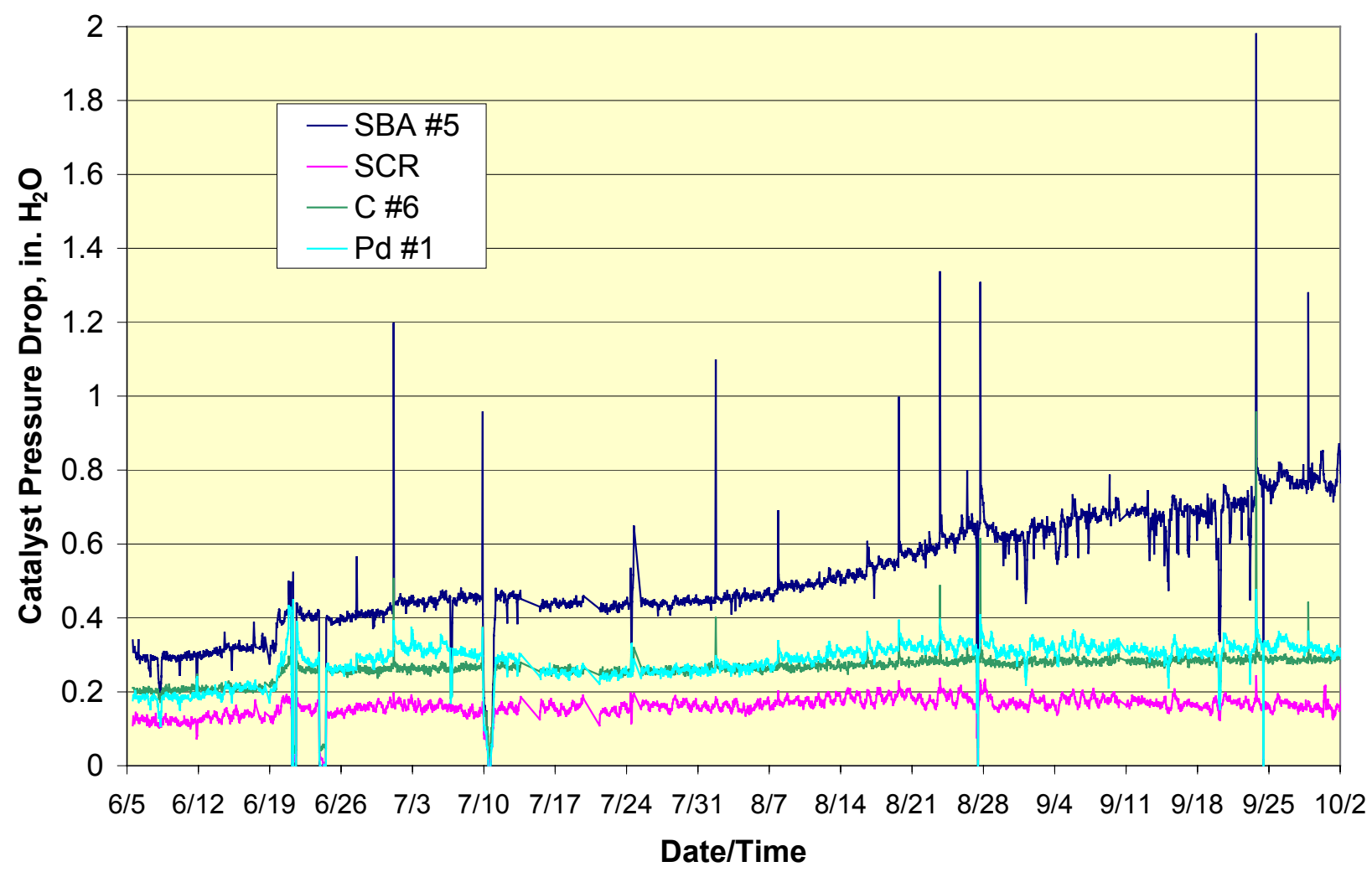

Figure 1. Pressure Drop Data for the Catalysts in Service at CCS, June through September.

In Figure 1, two periods of near zero pressure drop across all four catalysts are due to a loss of compressed air to the pilot unit. The pilot control valves are operated with compressed air from the CCS Station "non-essential" air system. The station lost air pressure in the non-essential air system twice in June, and the "fail-closed" control valves shut off flue gas flow until air pressure was restored. There are other upset periods seen on the plot that remain unexplained; most are apparently just glitches in the recorded data.

One catalyst activity measurement trip was made to CCS during the quarter, the week of July 21 . The pilot unit was found off line the morning of July 21 due to a power loss to the unit over the weekend. The pilot unit was restarted, but it is possible that some mercury desorbed from the catalysts during this period with no flue gas flow, causing some adsorption of mercury after gas flow resumed to restore adsorption equilibrium.

The results of the catalyst activity measurements (by SCEM) are shown in Table 1. As was expected, all four catalysts appeared to have been adsorbing a small amount of mercury from the inlet flue gas, ranging from 5\% apparent adsorption by the SCR catalyst to $32 \%$ adsorption for the $\mathrm{C} \# 6$ catalyst. In spite of this apparent adsorption, catalyst activity measurements were made. The activity of the $\mathrm{C} \# 6$ and $\mathrm{Pd} \# 1$ catalysts remained high, at greater than $90 \% \mathrm{Hg}^{0}$ oxidation across the $\mathrm{C} \# 6$ catalyst and greater than $80 \% \mathrm{Hg}^{0}$ oxidation across the $\mathrm{Pd} \# 1$. However, the 
measured activity for each was slightly lower than was measured in June. The apparent activity of the SBA \#5 and SCR catalysts continue to decline over time, to about $40 \% \mathrm{Hg}^{0}$ oxidation across the SBA \#5 catalyst and $20 \%$ oxidation across the SCR catalyst.

Table 1. Oxidation Catalyst Activity Results for CCS Pilot (measured by Hg SCEM)

\begin{tabular}{|c|c|c|c|c|c|}
\hline Location & $\begin{array}{c}\text { Total } \mathbf{H g} \\
\left(\mu \mathrm{g} / \mathrm{Nm}^{3},\right. \\
\text { corrected to } \\
\left.5 \% \mathrm{O}_{2}\right)\end{array}$ & $\begin{array}{c}\text { Elemental } \\
\mathrm{Hg}\left(\mu \mathrm{g} / \mathrm{Nm}^{3},\right. \\
\text { corrected to } \\
\left.5 \% \mathrm{O}_{2}\right)\end{array}$ & $\begin{array}{c}\text { Apparent } \\
\text { Total Hg } \\
\text { Adsorption } \\
\text { Across } \\
\text { Catalyst, \% } \\
\end{array}$ & $\begin{array}{c}\text { Apparent } \\
\text { Hg }^{0} \\
\text { Oxidation } \\
\text { Across } \\
\text { Catalyst, \% } \\
\end{array}$ & $\begin{array}{c}\text { Overall Hg } \\
\text { Oxidation } \\
\text { Percentage }\end{array}$ \\
\hline \multicolumn{6}{|c|}{ Results from $7 / 22 / 03$ : } \\
\hline Pilot Inlet & 14.0 & 10.0 & - & - & 28 \\
\hline $\begin{array}{l}\text { SBA \#5 } \\
\text { Outlet }\end{array}$ & 12.0 & 6.15 & 15 & 39 & 49 \\
\hline C \#6 Outlet & 9.53 & 0.65 & 32 & 94 & 93 \\
\hline \multicolumn{6}{|c|}{ Results from 7/23/03: } \\
\hline Pilot Inlet & 13.2 & 9.84 & - & - & 25 \\
\hline SCR Outlet & 12.7 & 7.77 & 5 & 21 & 39 \\
\hline Pd \#1 Outlet & 11.2 & 1.68 & 15 & 83 & 85 \\
\hline $\begin{array}{l}\text { SBA \#5 } \\
\text { Outlet }\end{array}$ & - & 5.85 & - & 39 & - \\
\hline C \#6 Outlet & - & 0.69 & - & 93 & - \\
\hline
\end{tabular}

The activity results for all four catalysts are plotted versus time in Figures 2 and 3, with the higher activity results for $\mathrm{Pd} \# 1$ and $\mathrm{C} \# 6$ plotted in Figure 2 and the lower activity results for SBA \#5 and the SCR catalyst in Figure 3. The plots show a downward trend in the clean catalyst activity measurements for all four catalysts, although the slope is greater for the less active catalysts. More time is needed and more measurements will be required to accurately determine the change in activity versus time for the more active Pd \#1 and C \#6 catalysts. For example, the slight downward trend seen for the $\mathrm{C} \# 6$ catalyst activity between the June and July measurements may be influenced by trip-to-trip measurement variation.

Also during the week of July 21, additional measurements were made across the CCS pilot unit. These included measurements of potential $\mathrm{SO}_{2}$ oxidation across the $\mathrm{SBA} \# 5$ and $\mathrm{C} \# 6$ catalysts (the other two catalysts were measured last October), measurement of potential $\mathrm{NO}$ to $\mathrm{NO}_{2}$ oxidation across all four catalysts, and Hg SCEM relative accuracy tests for all four catalysts by the Ontario Hydro method. The oxidation of $\mathrm{SO}_{2}$ to $\mathrm{SO}_{3}$ /vapor phase sulfuric acid across the SBA \#5 and C \#6 catalyst was measured by conducting simultaneous Controlled Condensation measurements at the pilot unit inlet and outlet of each catalyst, in triplicate runs. The results of these measurements are summarized in Table 2, and show no significant oxidation across either catalyst (less than $0.1 \%$ conversion of $\mathrm{SO}_{2}$ to $\mathrm{SO}_{3}$ ). Also shown in the table are the flue gas $\mathrm{SO}_{2}$ concentrations that were measured simultaneously at each measurement location.

The oxidation of $\mathrm{NO}$ to $\mathrm{NO}_{2}$ across the catalysts was measured with a chemiluminescence $\mathrm{NO}_{\mathrm{X}}$ gas analyzer that was cycled between the pilot unit inlet and the outlet gas from each of the four catalysts. The analyzer measured both $\mathrm{NO}$ and total $\mathrm{NO}_{\mathrm{X}}$ at each location. These results are 
summarized in Table 3. No conversion of $\mathrm{NO}$ to $\mathrm{NO}_{2}$ was measured across any of the four

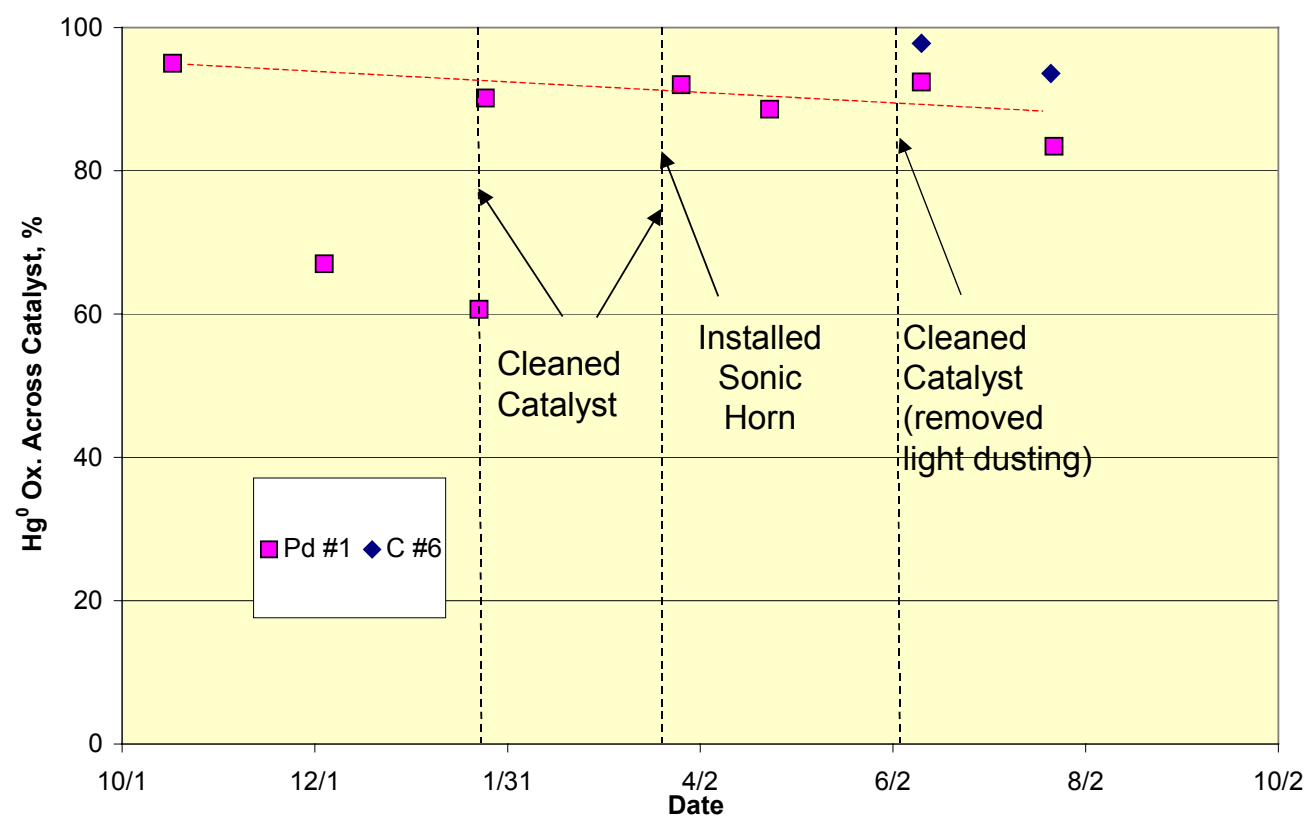

catalysts, as the $\mathrm{NO}$ and total $\mathrm{NO}_{\mathrm{x}}$ concentrations were identical at each of the four outlet gas locations $\left(\mathrm{NO}_{2}\right.$ concentrations would be indicated by the difference between these two values).

Figure 2. Activity for $\mathrm{Hg}^{0}$ Oxidation versus Time for $\mathrm{Pd} \# 1$ and $\mathrm{C} \# 6$ Catalysts at CCS.

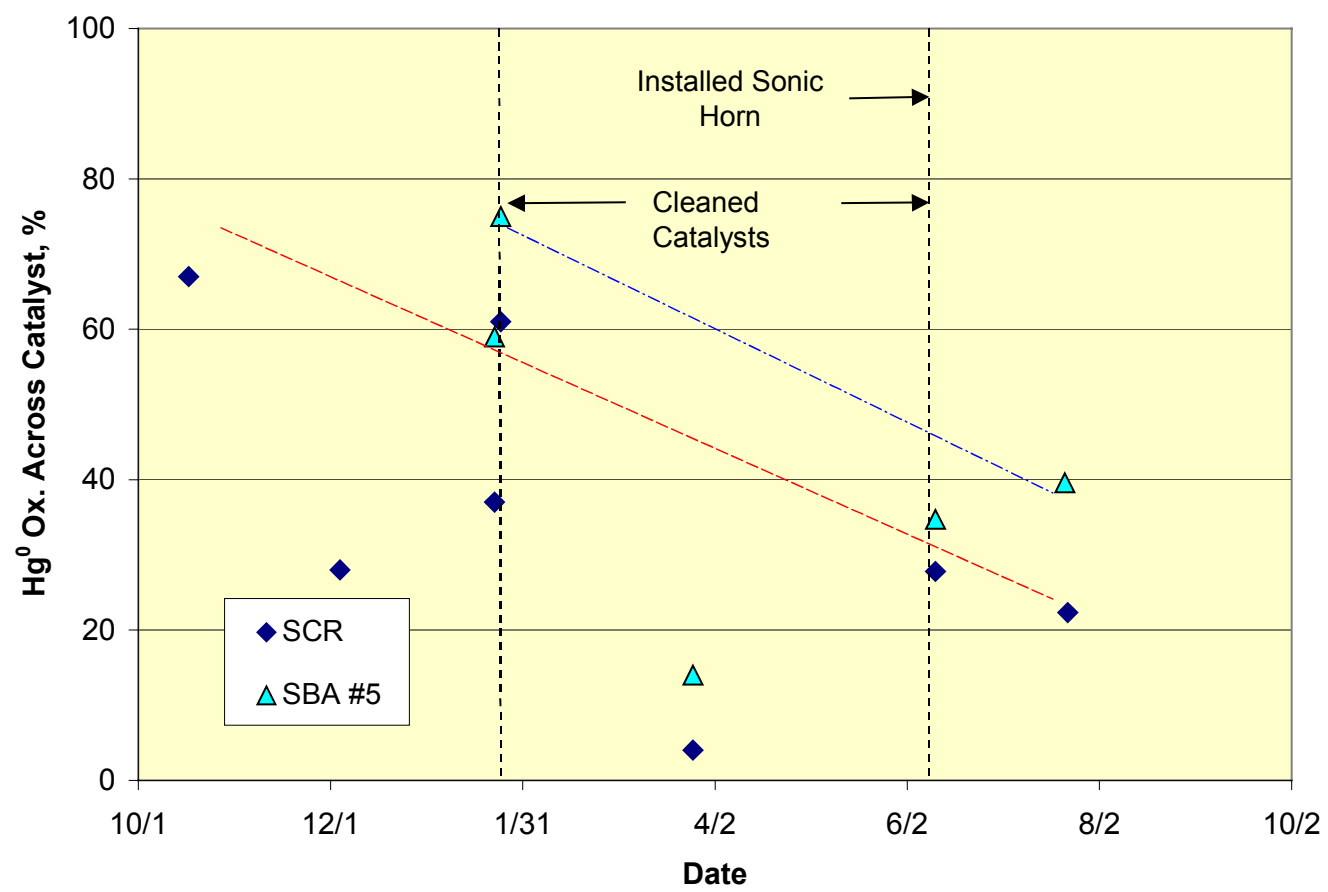

Figure 3. Activity for $\mathrm{Hg}^{0}$ Oxidation versus Time for SCR and SBA \#5 Catalysts at CCS. 
Table 2. Summary of Measurements of $\mathrm{SO}_{2}$ to $\mathrm{SO}_{3}$ Oxidation Across the SBA \#5 and C \#6 Catalysts at CCS

\begin{tabular}{|l|c|c|c|}
\hline \multicolumn{1}{|c|}{ Parameter } & Pilot Unit Inlet & SBA \#5 Outlet & C \#6 Outlet \\
\hline $\begin{array}{l}\text { Run } \mathrm{SO}_{3} \text { Concentration (ppmv } \\
\text { dry basis) }\end{array}$ & 0.34 & 1.12 & 0.94 \\
\hline $\begin{array}{l}\text { Run 2 } \mathrm{SO}_{3} \text { Concentration (ppmv } \\
\text { dry basis) }\end{array}$ & 0.39 & 1.26 & 1.14 \\
\hline $\begin{array}{l}\text { Run 3 } \mathrm{SO}_{3} \text { Concentration (ppmv } \\
\text { dry basis) }\end{array}$ & 0.34 & 1.23 & 1.44 \\
\hline $\begin{array}{l}\text { Average } \mathrm{SO}_{3} \text { Concentration } \\
\text { (ppmv dry basis) }\end{array}$ & 0.35 & 1.21 & 1.17 \\
\hline $\begin{array}{l}\text { Measured } \mathrm{SO}_{2} \text { Concentration } \\
\text { (ppmv dry basis) }\end{array}$ & 1027 & 909 & 975 \\
\hline $\begin{array}{l}\text { Apparent } \mathrm{SO}_{2} \text { to } \mathrm{SO}_{3} \text { Conversion } \\
\text { Across Catalyst }(\%)\end{array}$ & - & 0.08 & 0.08 \\
\hline
\end{tabular}

Table 3. Summary of Measurements of $\mathrm{NO}$ to $\mathrm{NO}_{2}$ Oxidation Across the $\mathrm{Hg}^{0}$ Oxidation Catalysts and $\mathrm{SO}_{2}$ Concentrations at CCS (all measurements by portable CEM)

\begin{tabular}{|l|c|c|c|c|}
\hline \multicolumn{1}{|c|}{ Location } & $\begin{array}{c}\text { NO (ppmv at } \\
\left.\mathbf{5 \%} \mathbf{O}_{2}\right)\end{array}$ & $\begin{array}{c}\text { NOx } \\
\mathbf{( p p m v ~ a t ~} \\
\left.\mathbf{5 \%} \mathbf{O}_{2}\right)\end{array}$ & $\begin{array}{c}\text { Apparent } \\
\text { Conversion of } \\
\text { NO to NO } \mathbf{~ ( \% )}\end{array}$ & $\begin{array}{c}\mathbf{S O}_{\mathbf{2}}(\mathbf{p p m v} \text { at } \\
\left.\mathbf{5 \%} \mathbf{O}_{\mathbf{2}}\right)\end{array}$ \\
\hline Pilot Unit Inlet & 122 & 122 & 0.00 & 973 \\
\hline SBA \#5 Inlet & 119 & 119 & 0.00 & 962 \\
\hline SCR Inlet & 120 & 120 & 0.00 & 946 \\
\hline C \#6 Inlet & 129 & 129 & 0.00 & 962 \\
\hline Pd \#1 Inlet & 130 & 130 & 0.00 & 974 \\
\hline
\end{tabular}

While the results of the measurements of $\mathrm{SO}_{2}$ to $\mathrm{SO}_{3}$ conversion and $\mathrm{NO}$ to $\mathrm{NO}_{2}$ conversion were quite positive, the results of the Hg SCEM relative accuracy tests by the Ontario Hydro $(\mathrm{OH})$ method were more troubling. In the October 2002 relative accuracy tests at CCS, measured across the Pd \#1 and SCR catalysts, the Hg SCEM and $\mathrm{OH}$ measurements were almost identical. However, in the July 2003 relative accuracy tests across all four catalysts, there were significant differences between the measurement results by the two methods. This comparison is made in Table 4. For clarity, the $\mathrm{OH}$ results at each location are shown in bold text, while the SCEM results at each location are shown in normal text.

At the pilot unit inlet, the SCEM results showed 15 to $27 \%$ lower concentrations for both total and elemental mercury than did the $\mathrm{OH}$ results, but the inlet flue gas mercury oxidation percentages were similar for both measurement types (approximately 25\%). The oxidized mercury concentration measured by the two methods compared more favorably, with the SCEM results being within 1 to $2 \%$ of the $\mathrm{OH}$ concentrations. This relatively consistent bias seen in the comparison of results for the two methods at the pilot unit inlet is not a major concern. 
Table 4. Comparison of Ontario Hydro Results with EPRI Mercury Semi-continuous Emissions Monitor Results from CCS, July 2003 (all values corrected to $5 \% \mathrm{O}_{2}$ in flue gas)

\begin{tabular}{|c|c|c|c|c|c|c|}
\hline & \multicolumn{3}{|c|}{ Hg Concentration $\left(\mu \mathrm{g} / \mathrm{Nm}^{3}\right)$} & \multirow[b]{2}{*}{$\begin{array}{c}\text { Total Hg } \\
\text { Oxidation } \\
(\%) \\
\end{array}$} & \multirow{2}{*}{$\begin{array}{c}\mathbf{H g}^{\mathbf{0}} \\
\text { Oxidation } \\
\text { Across } \\
\text { Catalyst } \\
(\%)\end{array}$} \\
\hline & & $\mathrm{Hg}^{+2}$ & $\mathbf{H g}^{0}$ & Total & & \\
\hline \multirow[t]{2}{*}{ Pilot Inlet - 7/22 } & $\mathbf{O H}$ & 4.06 & 12.3 & 16.4 & 25 & - \\
\hline & SCEM & 3.99 & 10.0 & 14.0 & 28 & - \\
\hline \multirow[t]{2}{*}{ Pilot Inlet - 7/23 } & OH & 3.36 & 13.5 & 16.8 & 20 & - \\
\hline & SCEM & 3.40 & 9.84 & 13.2 & 25 & - \\
\hline \multicolumn{7}{|l|}{ Pilot Outlet: } \\
\hline \multirow{2}{*}{$\begin{array}{l}\text { SBA \#5 - 7/22 } \\
(2000 \mathrm{acfm})\end{array}$} & $\mathbf{O H}$ & 11.1 & 3.80 & 14.9 & 75 & 69 \\
\hline & SCEM & 5.80 & 6.15 & 12.0 & 49 & 39 \\
\hline \multirow{2}{*}{$\begin{array}{l}\text { SCR }-7 / 23 \\
(1500 \mathrm{acfm})\end{array}$} & OH & 14.0 & 1.17 & 15.2 & 92 & 92 \\
\hline & SCEM & 4.89 & 7.77 & 12.7 & 39 & 21 \\
\hline \multirow{2}{*}{$\begin{array}{l}\text { C \#6 - 7/22 } \\
(2000 \mathrm{acfm})\end{array}$} & OH & 14.2 & 0.30 & 14.5 & 98 & 98 \\
\hline & SCEM & 8.88 & 0.65 & 9.53 & 93 & 94 \\
\hline \multirow{2}{*}{$\begin{array}{l}\mathrm{Pd} \# 1-7 / 23 \\
(2000 \mathrm{acfm})\end{array}$} & OH & 13.6 & 1.58 & 15.2 & 90 & 90 \\
\hline & SCEM & 9.54 & 1.68 & 11.2 & 85 & 83 \\
\hline
\end{tabular}

At the catalyst outlets, the total mercury concentrations were lower in the SCEM results than in the $\mathrm{OH}$ results, as was seen for the pilot unit inlet measurements. However, the elemental mercury concentration measurements for three of the four catalyst outlets were significantly higher in the SCEM results than in the $\mathrm{OH}$ results, which runs opposite the trend seen at the pilot inlet. For one catalyst $(\mathrm{Pd} \# 1)$ the elemental mercury concentrations measured by the two methods were similar.

With the catalyst outlet total mercury values being lower in the SCEM results than in the OH results, while the elemental mercury concentrations were higher than the OH results, the SCEM results at the catalyst outlets showed significantly lower oxidized mercury concentrations and lower oxidation percentages than in the OH results. Similarly, the SCEM results showed lower elemental mercury oxidation percentages across the catalysts than in the $\mathrm{OH}$ results. In the case of the SCR catalyst, the difference between the two method results for elemental mercury oxidation across the catalyst was profound, with the $\mathrm{OH}$ method indicating $92 \%$ oxidation while the SCEM showed only $21 \%$.

One's first inclination is to suspect the SCEM results as being erroneous, since the OH method is a favored method by which mercury concentrations are to be measured in flue gases from coal firing. However, for the SCR catalyst, it is the $\mathrm{OH}$ results that appear to be suspect. In October 2002 , both the $\mathrm{OH}$ and SCEM results for that catalyst showed between 65 and $70 \%$ oxidation of elemental mercury across the catalyst. Since last October, the SCEM has showed a steady decrease in oxidation activity for this catalyst when in a "clean" condition (no fly ash buildup). The elemental mercury oxidation seen across this catalyst in the July $\mathrm{OH}$ results $(92 \%)$ is 
significantly higher than in the initial $\mathrm{OH}$ results for this catalyst from last October. Since it is unlikely that the catalyst activity improved markedly after 10 months of operation in flue gas, the $\mathrm{OH}$ results for the SCR catalyst outlet location appear to be suspect.

It is not apparent what might have caused the bias seen in the comparison of results from the two methods. Since the catalyst outlet elemental mercury numbers are lower in the $\mathrm{OH}$ results than in the SCEM results, one might suspect a sample train leak or some effect that caused poor capture of elemental mercury in the $\mathrm{OH}$ measurement train. However, the total mercury concentrations measured by the $\mathrm{OH}$ method at the catalyst outlets are quite consistent, and close to the totals measured at the inlet, so neither of these potential problems are evident. In the SCEM results, the total mercury concentrations are lower than in the $\mathrm{OH}$ results, which could indicate a sample train leak or adsorption of mercury somewhere in the sample train. However, neither of these potential problems could explain the higher elemental mercury concentrations measured by the SCEM compared to the $\mathrm{OH}$ results. Under some sampling conditions, the inertial gas separator used in the pilot unit to separate any fly ash from the sample gas upstream of the gas conditioning impingers has reportedly been shown by other researchers to oxidize a portion of the elemental mercury in the sample gas. However, this effect runs opposite the observed bias, where the oxidation percentages measured at the catalyst outlets were typically lower in the SCEM results than in the $\mathrm{OH}$ results.

There are no known differences in SCEM operation between October 2002 and July 2003, but two known differences between the October and July OH measurement efforts. One is that in October, sodium thiosulfate was added to the $\mathrm{KCl}$ solution in the $\mathrm{OH}$ train based on advice attributed to Jeff Ryan of EPA. The thiosulfate was reportedly added to quench free chlorine in the sample gas. By the time of the July 2003 measurements, the OH method had been standardized as an ASTM method, so the ASTM method (which does not include thiosulfate addition to the $\mathrm{KCl}$ solution) was employed. The significance of this change is not known at this time, but warrants further consideration. The second difference, which is not thought to be significant, is that in July the $\mathrm{KCl}$ solutions were mixed at $86 \%$ of the ASTM-specified concentration due to a math error in calculating the $\mathrm{KCl}$ reagent mass needed. This error, if it had been significant, would have had the effect of reducing oxidized mercury recovery in the $\mathrm{OH}$ train, which was not apparent in the results.

Over the next quarter, the SCEM and $\mathrm{OH}$ results from July will be further reviewed and investigated in an attempt to determine the cause of the significant biases between the results from the two methods at the catalyst outlet locations.

\section{Laboratory Evaluation of Candidate Catalysts}

No laboratory evaluations were conducted during the current quarter.

\section{Catalyst Supply}

In July, the required catalyst dimensions for the pilot unit at Spruce Plant were determined based on laboratory and CCS activity results, and all four catalysts were ordered from their respective suppliers. Table 5 summarizes the catalyst dimensions. The Pd \#1 and Au catalysts were delivered from Süd-Chemie Prototech in August. The SCR catalyst was not delivered at Spruce 
Plant until September 29, due to the Argillon production facilities shutting down in August for summer vacation. The $\mathrm{C} \# 6$ catalyst is taking the longest time to procure because of the multiple process steps by several subcontractors that have to take place to produce this material in honeycomb catalyst form. It is expected to be delivered to Spruce Plant by late October.

Table 5. Catalyst Dimensions for Oxidation Catalyst Pilot Unit at Spruce Plant

\begin{tabular}{|l|c|c|c|c|}
\hline \multicolumn{1}{|c|}{ Catalyst } & $\begin{array}{c}\text { Cells per in. } \\
\text { (cpsi) }\end{array}$ & $\begin{array}{c}\text { Cross Section } \\
\text { (in. } \times \text { in.) }\end{array}$ & Length (in.) & $\begin{array}{c}\text { Area Velocity } \\
\text { (sft/hr) }\end{array}$ \\
\hline $\mathrm{Pd} \mathrm{\# 1}$ & 64 & $30 \times 30$ & 9 & 49 \\
\hline $\mathrm{Au}$ & 64 & $30 \times 30$ & 9 & 49 \\
\hline $\mathrm{C} \mathrm{\# 6}$ & $80^{*}$ & $36 \times 36$ & 9 & 27 \\
\hline $\mathrm{SCR}$ & 46 & $35.4 \times 35.4$ & 29.5 & 13 \\
\hline
\end{tabular}

*Die is sized at 64 cpsi, but shrinkage to this pitch is expected on drying

\section{Pilot Unit Operation at Spruce Plant}

The pilot unit installation at Spruce Plant was completed by CPS personnel the week of August 11, and the pilot unit was started up on flue gas (without catalysts) that week. The first two catalysts, Pd \#1 and Au, arrived from Süd-Chemie Prototech the week of August 18, and were installed the following week. The pilot unit was started up with these two catalysts installed on August 28, and left in operation until the host unit came off line for a fall outage the evening of September 26. The outage is planned to continue until October 27.

The objectives of this initial one-month of operation were to ensure proper pilot unit operation, collect host site flue gas mercury concentration and speciation data, determine initial catalyst activity for these two catalysts in the PRB flue gas, and to provide an indication whether sonic horns will be needed to avoid fly ash buildup on the catalysts at this site.

The pilot unit controlled temperature and flow rate through the catalyst chambers well over this period, but a few problems were noted. One was that in the Texas climate and with the western exposure of the pilot unit, the temperature inside the pilot unit control box was going up well over $100^{\circ} \mathrm{F}$, which is too hot for the electronic controls and data logging computer. To address this problem, a vortex cooler was retrofitted to the box, with a set point maximum temperature of $90^{\circ} \mathrm{F}$. A second problem was that we were not able to establish telephone communications with the pilot unit data logger due to line quality problems. The plant replaced the original line with shielded cable, and eventually had to change the source of the phone line connection in the plant to provide adequate signal quality, although this did not occur until the day the unit came off line. Ongoing problems include a failed gauge-pressure transducer on one of the catalyst chambers, which is being replaced, and a lack of differential indication from any of the catalyst chamber pressure drop transducers. The latter problem still remains to be further investigated and resolved. 
Host site flue gas mercury concentration data were collected on three occasions, mid-August, early September, and late September. These results are summarized in Table 6. The measurements at the pilot unit inlet showed much higher mercury oxidation percentages than were expected, typically over $75 \%$ oxidized, rather than the expected 20 to $30 \%$ oxidized mercury as is typical of PRB flue gases. This was theorized to be an influence of the baghouse conditions at Spruce, which operates at a very low air-to-cloth ratio (less than $1.5 \mathrm{acfm} / \mathrm{ft}^{2}$ ), has aged bags (11 years old) and has a permanent dust cake that has possibly been influenced by pet coke co-firing (last fired December 2002). All of these effects could lead to increased mercury oxidation across the bags, such as due to increased gas/dust cake contact at the low air to cloth ratio and/or the influence of vanadium and/or unburned carbon in the permanent dust cake due to prior pet coke co-firing.

Table 6. Flue Gas Mercury Concentrations and Speciation at Spruce Plant (measured by Hg SCEM)

\begin{tabular}{|c|c|c|c|}
\hline Date & $\begin{array}{c}\text { Total } \mathrm{Hg}\left(\mu \mathrm{g} / \mathrm{Nm}^{3},\right. \\
\left.\text { corrected to } 5 \% \mathrm{O}_{2}\right)\end{array}$ & $\begin{array}{c}\text { Elemental } \mathrm{Hg} \\
\left(\mu \mathrm{g} / \mathrm{Nm}^{3}, \text { corrected }\right. \\
\left.\text { to } 5 \% \mathrm{O}_{2}\right)\end{array}$ & Hg Oxidation (\%) \\
\hline \multicolumn{4}{|c|}{ Pilot Unit Inlet: } \\
\hline $8 / 21 / 03$ & 7.6 & 1.1 & 86 \\
\hline $9 / 2 / 03$ & 11.6 & 2.9 & 75 \\
\hline 9/24/03 (a.m.) & 8.4 & 1.4 & 84 \\
\hline 9/24/03 (p.m.) & 11.9 & 1.4 & 89 \\
\hline \multicolumn{4}{|c|}{ Baghouse Inlet: } \\
\hline $9 / 23 / 03$ & 20.3 & 19.3 & 5 \\
\hline
\end{tabular}

This theory was supported by measurements made at the baghouse inlet the week of September 22, using the EPRI Hg SCEM. These results are also included in Table 6. The baghouse inlet flue gas was found to have a total mercury concentration of $20 \mu \mathrm{g} / \mathrm{Nm}^{3}$, with only $5 \%$ mercury oxidation. On the following day, the pilot unit inlet flue gas (downstream of the baghouse and ID fan) was found to have a total mercury concentration of 8 to $12 \mu \mathrm{g} / \mathrm{Nm}^{3}$, with an average of about $85 \%$ oxidation. This indicates both mercury removal and oxidation across the baghouse.

Catalyst performance was measured on two occasions, on September 2 and September 24. These results are shown in Table 7. On September 2, after just a few days of catalyst operation, the pilot unit inlet total mercury was measured at $12 \mu \mathrm{g} / \mathrm{Nm}^{3}$, while the total mercury at the two catalyst outlets were considerably lower, at 6 to $10 \mu \mathrm{g} / \mathrm{Nm}^{3}$. This indicates that both catalysts were still adsorbing mercury from the flue gas. The inlet elemental mercury measured almost 3 $\mu \mathrm{g} / \mathrm{Nm}^{3}$, while the outlets from both catalysts measured about $0.5 \mu \mathrm{g} / \mathrm{Nm}^{3}$ of elemental mercury. Ignoring possible effects from mercury adsorption, both catalysts appeared to be achieving greater than $80 \%$ oxidation of the inlet elemental mercury. 
Table 7. Oxidation Catalyst Activity Results for Spruce Pilot (measured by Hg SCEM)

\begin{tabular}{|c|c|c|c|c|c|}
\hline Location & $\begin{array}{c}\text { Total } \mathbf{H g} \\
\left(\mu \mathrm{g} / \mathrm{Nm}^{3},\right. \\
\text { corrected to } \\
\left.5 \% \mathrm{O}_{2}\right)\end{array}$ & $\begin{array}{c}\text { Elemental } \\
\mathrm{Hg}\left(\mu \mathrm{g} / \mathrm{Nm}^{3},\right. \\
\text { corrected to } \\
\left.5 \% \mathrm{O}_{2}\right)\end{array}$ & $\begin{array}{c}\text { Apparent } \\
\text { Total Hg } \\
\text { Adsorption } \\
\text { Across } \\
\text { Catalyst, \% }\end{array}$ & $\begin{array}{c}\text { Apparent } \\
\text { Hg }^{0} \\
\text { Oxidation } \\
\text { Across } \\
\text { Catalyst, \% }\end{array}$ & $\begin{array}{c}\text { Overall Hg } \\
\text { Oxidation } \\
\text { Percentage }\end{array}$ \\
\hline \multicolumn{6}{|c|}{ Results from 9/2/03 (2000 acfm through each catalyst): } \\
\hline Pilot Inlet & 11.6 & 2.9 & - & - & 75 \\
\hline Pd \#1 Outlet & 6.3 & 0.50 & 46 & 83 & 92 \\
\hline $\mathrm{Au}$ Outlet & 9.9 & 0.47 & 14 & 84 & 95 \\
\hline \multicolumn{6}{|c|}{ Results from 9/24/03 (2000 acfm through each catalyst): } \\
\hline Pilot Inlet & 8.4 & 1.4 & - & - & 84 \\
\hline Pd \#1 Outlet & 8.6 & 0.25 & - & 82 & 97 \\
\hline Au Outlet & 8.9 & 0.23 & - & 84 & 97 \\
\hline \multicolumn{6}{|c|}{ Results from 9/24/03 (1500 acfm through each catalyst): } \\
\hline Pilot Inlet & 11.9 & 1.4 & - & - & 89 \\
\hline Pd \#1 Outlet & 11.3 & 0.19 & - & 86 & 98 \\
\hline $\mathrm{Au}$ Outlet & 12.0 & 0.23 & - & 83 & 98 \\
\hline
\end{tabular}

On September 24, catalyst activity was measured at two flue gas flow rates, 2000 acfm through each catalyst in the morning and $1500 \mathrm{acfm}$ in the afternoon. In the morning, the inlet total mercury averaged about $8 \mu \mathrm{g} / \mathrm{Nm}^{3}$, while the elemental mercury concentrations were measured at an average of $1.4 \mu \mathrm{g} / \mathrm{Nm}^{3}$. The outlet concentrations from both the $\mathrm{Pd} \# 1$ and Au catalysts were approximately 0.2 , indicating 82 to $84 \%$ oxidation of elemental mercury across both catalysts.

In the afternoon, the pilot unit inlet total mercury concentrations increased to nearly $12 \mu \mathrm{g} / \mathrm{Nm}^{3}$, although the average inlet elemental mercury concentration was not markedly increased. At the lower flue gas flow rate of $1500 \mathrm{acfm}$, the outlet elemental mercury concentrations from both the $\mathrm{Pd} \mathrm{\# 1}$ and $\mathrm{Au}$ catalysts were approximately 0.2 , indicating 83 to $86 \%$ oxidation of elemental mercury across each catalysts. Within the precision of these measurements, the performance of the $\mathrm{Pd} \# 1$ and Au catalysts was identical, and neither catalyst showed a significant effect of the flow rate change.

Because of the unresolved pressure drop transducer problem mentioned above, no trend plots could be made of catalyst pressure drop over time at Spruce. After four weeks of operation, the pressure drop across each catalyst chamber was about 0.25 in. $\mathrm{H}_{2} \mathrm{O}$, as measured manually with a water manometer on September 25. These values compare favorably (within 0.05 to 0.10 in. $\mathrm{H}_{2} \mathrm{O}$ ) with the "clean" pressure drop for the Pd \#1 catalyst at Coal Creek at the same flue gas flow rate. The pilot unit was brought off line on September 26 as the host unit came down for its fall outage, and inspected for fly ash buildup on September 29. Both chambers were very clean, with only a light dusting of fly ash. Figure 4 shows a close-up of one of the catalyst modules, showing that it has very little fly ash buildup, and Figure 5 shows a view of the chamber floor, again showing very little fly ash buildup. It appears that sonic horns will not be required at this host site, possibly because it is downstream of a baghouse rather than an ESP as at Coal Creek. 
The baghouse most likely results in a lower dust loading in the pilot unit inlet flue gas, and a dust loading that has less of a residual electrostatic charge than in flue gas downstream of an ESP.

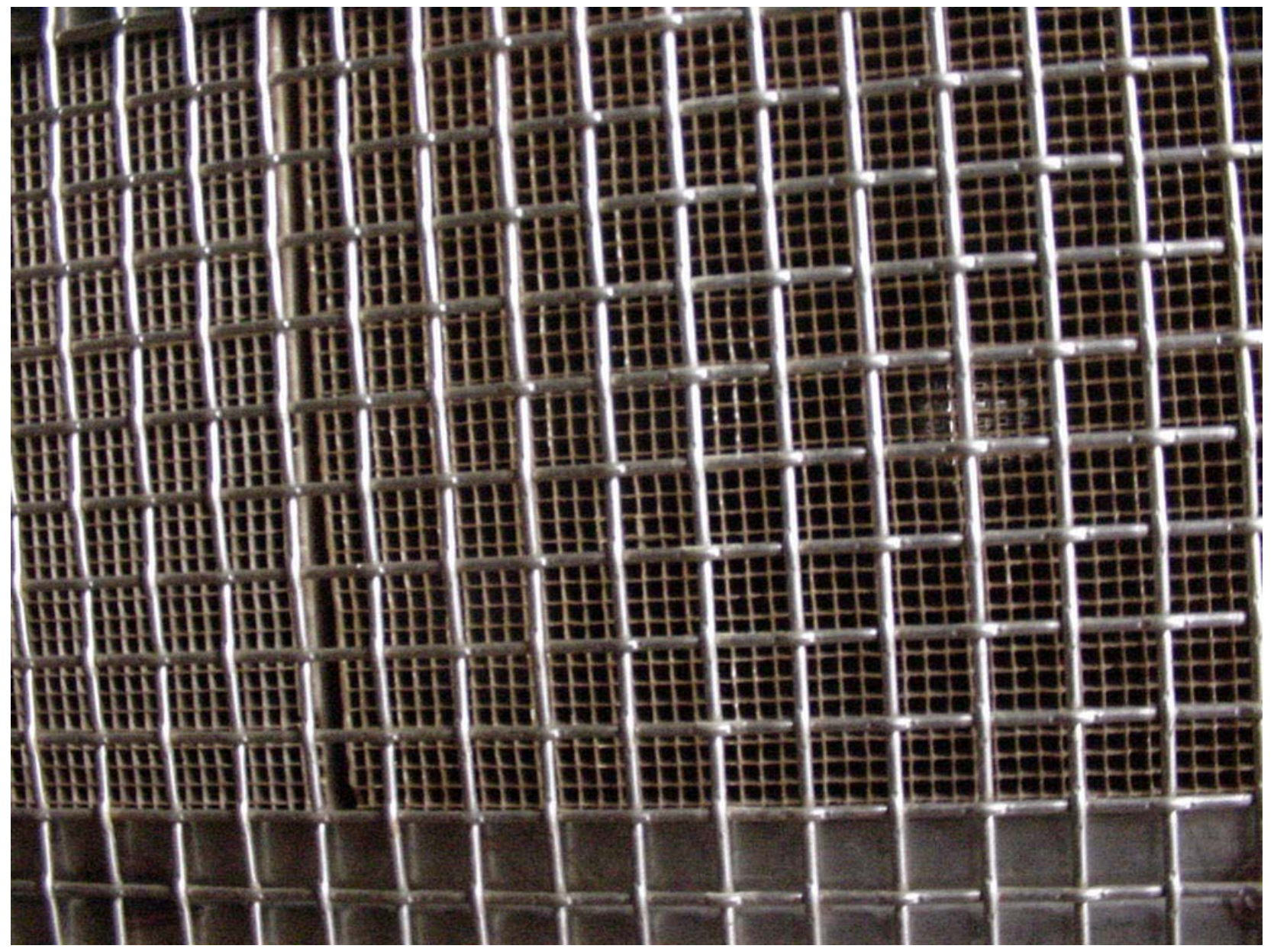

Figure 4. Close-up of One Catalyst Module after One Month of Operation at Spruce Plant 


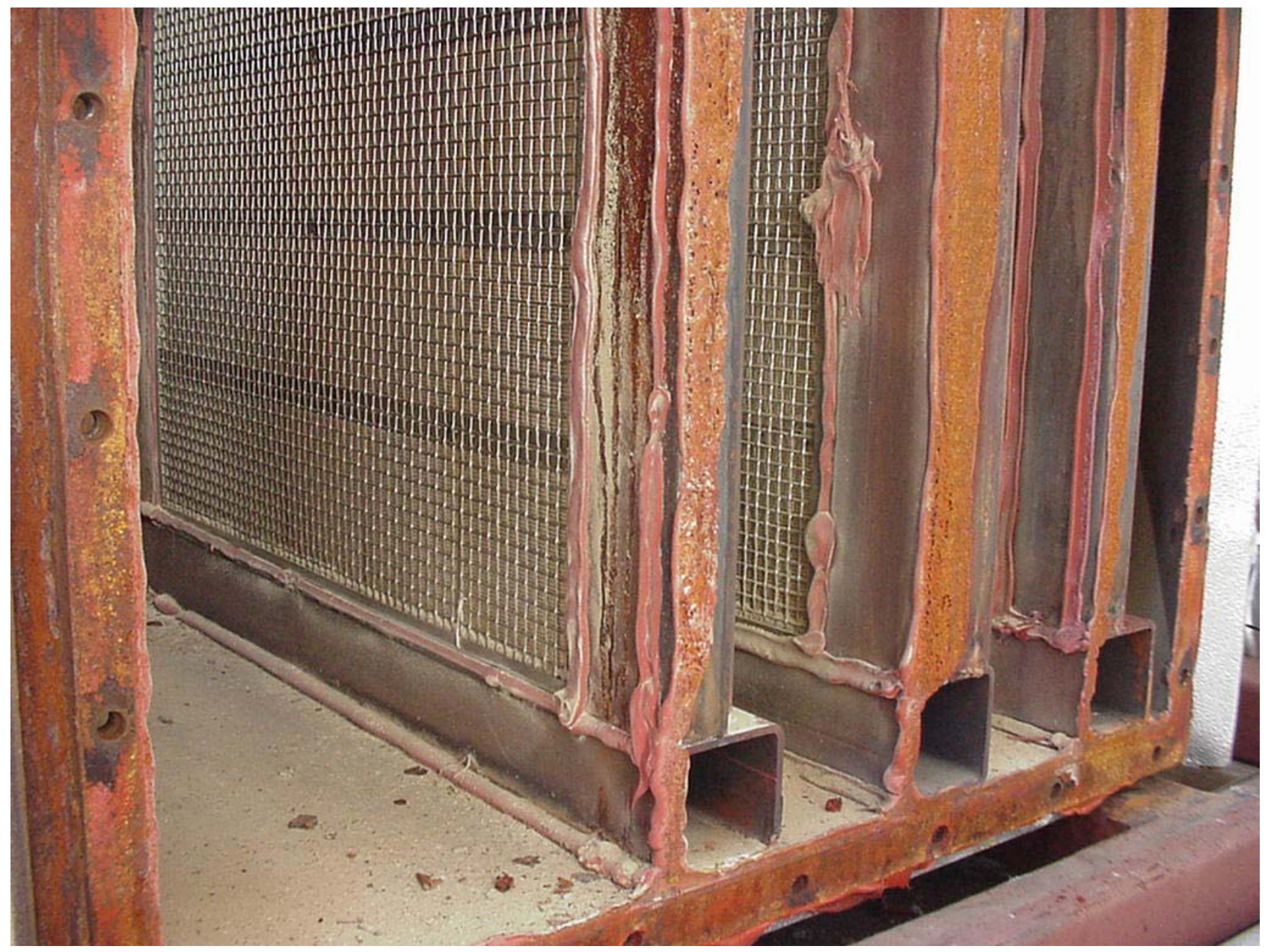

Figure 5. Photograph of a Catalyst Chamber at Spruce Showing Minimal Fly Ash Buildup after One Month of Operation 


\section{CONCLUSION}

In the initial six months of pilot unit operation, it became apparent that the potential for adverse effects from the ash remaining in the flue gas downstream of a high-efficiency ESP was underestimated at the beginning of the project. After two months of operation, the Pd \#1 and SCR catalysts had seen a significant loss of activity for $\mathrm{Hg}^{0}$ oxidation and a significant increase in pressure drop. Both of these effects were attributed to fly ash buildup within the catalyst chambers and within the flow channels of the catalyst honeycomb cells. Fortunately, the collected fly ash remained dry and free flowing, and was readily removed by blowing compressed air through the catalyst cells and vacuuming up loose fly ash.

Because of the observed ash accumulation on the catalysts at CCS, provisions had to be made to help keep catalyst surfaces cleaner. Sonic horns are commonly used to clean catalysts on line in utility SCR applications for $\mathrm{NO}_{\mathrm{X}}$ control, and appear to be similarly effective in this application (lower dust loading but horizontal gas flow). A trial application of a sonic horn was installed on the Pd \#1 catalyst chamber in late March, and was effective in limiting fly ash build up during two months of operation. Based on this success, similar sonic horns were installed on each of the other three chambers. In four months of operation, the horns appear to be effective at limiting fly ash buildup, as evident from low pressure drop values across three of the four catalysts. Catalyst activity measurements in July indicate that the horns have also been effective in maintaining high catalyst activity, at least for the more active catalyst materials.

After 10 months of operation, the Pd \#1 catalyst has apparently seen some loss in activity for elemental mercury oxidation. The SCR catalyst has seen a more significant loss, dropping from $67 \%$ to less than $30 \%$ oxidation over the same period (as measured by SCEM). The SBA \#5 catalyst has dropped from $75 \%$ oxidation to $39 \%$ oxidation over an 8 -month period (also based on SCEM results). However, all of these results are confounded by the fly ash buildup experienced prior to the sonic horn installations. The fly ash buildup could have had beneficial or negative effects on catalyst activity. If the catalysts can be deactivated by species in the flue gas, the honeycomb cells that were blocked by fly ash buildup may have been "protected" from deactivation by flue gas species. Conversely, the fly ash buildup could have directly affected catalyst activity in an adverse manner through physical blockage or chemical reactions at active sites. More operating time is needed on all four catalysts to quantify activity loss over time with the sonic horns in service to limit fly ash buildup.

None of the four catalysts appear to convert a significant amount of the flue gas $\mathrm{SO}_{2}$ to $\mathrm{SO}_{3}$, nor do they appear to convert $\mathrm{NO}$ to $\mathrm{NO}_{2}$. This is a positive finding about this process, as significant oxidation of either species in the flue gas would be undesirable.

The biggest concern about the results from this project is currently the relatively poor agreement between the $\mathrm{OH}$ method and the SCEM results at the catalyst outlets seen in the July 2003 relative accuracy test results. The $\mathrm{OH}$ results actually show better elemental mercury oxidation performance from the catalysts than is indicated from the SCEM results. However, the project team believes the more conservative performance results measured by the Hg SCEM are more reflective of actual catalyst performance. During the coming quarter, efforts will continue to attempt to resolve the apparent differences in results between the two methods at this site. 


\section{REFERENCES}

1. Blythe, Gary M. "Pilot Testing of Mercury Oxidation Catalysts for Upstream of Wet FGD Systems," Quarterly Technical Progress Report, October 1, 2002 - December 31, 2002. Cooperative Agreement No. DE-FC26-01NT41185, URS Corporation, Austin, Texas 78729. January 2003.

2. Blythe, Gary M. "Pilot Testing of Mercury Oxidation Catalysts for Upstream of Wet FGD Systems," Quarterly Technical Progress Report, July 1, 2002 - September 30, 2002. Cooperative Agreement No. DE-FC26-01NT41185, URS Corporation, Austin, Texas 78729. October 2002.

3. Blythe, Gary M. "Pilot Testing of Mercury Oxidation Catalysts for Upstream of Wet FGD Systems," Quarterly Technical Progress Report, March 1, 2002 - June 30, 2002. Cooperative Agreement No. DE-FC26-01NT41185, URS Corporation, Austin, Texas 78729. July 2002.

4. Blythe, Gary M. "Pilot Testing of Mercury Oxidation Catalysts for Upstream of Wet FGD Systems," Quarterly Technical Progress Report, January 1, 2002 - March 31, 2002.

Cooperative Agreement No. DE-FC26-01NT41185, URS Corporation, Austin, Texas 78729. April 2002.

5. Enhanced Control of Mercury by Wet Flue Gas Desulfurization Systems, Final Report, Phase II, U.S. Department of Energy Cooperative Agreement Number DE-AC22-95PC95260, URS Corporation, Austin, Texas 78729. June 2001. 